\title{
Flexible learning in a partnership context for beginning teachers
}

\author{
Brian M. Sova and Roger G. Hacker \\ The Graduate School of Education, University of Western Australia
}

A preliminary inventory was carried out for a sample of male and female student teachers who had email accounts. Preliminary inventory data revealed that the mean number of times per week that males used email was significantly higher than the mean number for female students. This inventory data indicated that characteristics such as gender affect Internet educational technology utilization, and this factor was addressed within the experimental design for the main study. In the main study, student teachers were assigned to four treatment groups for learning lesson-planning skills. The first two groups received a traditional university lecture followed by a seminar. For group 1, the seminar was provided at university. For group 2, the seminar was provided as part of the student's school-based experiences. Groups 3 and 4 received identical tuition to groups 1 and 2 respectively, except that tuition was provided on a flexible learning basis, being delivered electronically via the Internet with tutorial support from the university lecturer by way of asynchronous email. It was found that student achievement was significantly higher when tuition was provided as part of the student's school-based experiences, and also that achievement was significantly higher when tuition was provided on a flexible learning basis involving computermediated communications. A separate ANOVA was carried out for the entire sample of the four treatment groups in order to address the factor of student gender, which was controlled in the experiment. However, there were no significant differences in achievement associated with student gender. This surprising finding suggests that although male students may make greater usage of information technology, when required to do so, female students perform on a par with their male counterparts.

\section{Introduction}

Universities have been slow to adapt to technological change. As the Teaching and Learning Committee of the University of Western Australia observe in Alternative Modes of Teaching and Learning $(1996,2)$ :

The new world that is emerging values flexibility over rigidity, and process over content. Yet with our complex system of faculties and departments, courses and units, curricula and assessment, we offer students little control over their own learning. Our current model is predominantly didactic rather than negotiated, and we prefer to control learning resources, rather than offer them. Our school system is already adapting, restructuring and adopting technology to make the curricula more relevant to individual learners' characteristics, to make learning more active, and to empower students to take 
responsibility for their own learning. Students will come to expect no less from their tertiary experiences.

Teacher educators have been slow to realize the potential of technological change. Where computer-mediated delivery has been used to educate teachers, it has been mostly in the field of Continuing Teacher Education (CTE) and some universities now offer postgraduate teacher-education programmes via flexible delivery involving off-campus, computermediated delivery. In the area of Initial Teacher Education (ITE) there has been less experimentation. Selinger (1996) describes an 18-month, part-time, distance-taught PGCE offered by the Open University for potential primary and secondary teachers who were unable to attend a full-time course. However, this programme was delivered mainly via the traditional Open University print media packages, with the use of information technology in this programme being restricted to synchronous/asynchronous email for tutorial support and text-based conferences. Otherwise, there has been little reported experimentation with flexible delivery in ITE programmes, and little or no work has been done which involves comparing the efficacy of flexible delivery compared with traditional university teaching.

In recent years, partnership models, which involve students spending a greater proportion of their time in schools, have become fashionable with teacher educators. However, as with computer-mediated delivery, little is known about the efficacy of a partnership model when compared with the traditional alternative. The study reported here aims to explore the efficacy of these two innovations with respect to the delivery of a courseware module for ITE. The null hypotheses tested were: (1) that the efficacy of computer-mediated delivery of courseware is not different from that of traditional, university delivery methods, and (2) that the efficacy of learning in partnership with schools is not significantly different from university-based learning.

\section{Methods}

Preliminary inventory methods. Student teachers were randomly approached at the University of Western Australia and asked to complete inventory forms. The sample of student teachers included male $(\mathrm{N}=14)$ as well as female $(\mathrm{N}=21)$ students. Inventory form questions included one which asked students to indicate their gender and one which asked those students with an email account to indicate the approximate number of times per week they checked them.

Main study sample. The sample comprised 43 student teachers of science, studying a lesson-planning courseware module as part of their Diploma in Education programme. Science was the major teaching area for 21 students who had studied a science to at least the third year of their undergraduate programme. It was a minor teaching area for 22 of the students who had studied a science to the second year of their undergraduate programme. Eighteen of the students were male and 25 female. All of the students studied the same courseware designed to develop lesson planning skills, which comprised a lecture followed by a seminar.

The students were assigned to four treatment groups. The assignment was purposive with respect to the level to which science had been studied successfully in the student's undergraduate programme and with respect to student gender, as it was thought that these variables might also influence achievement. 


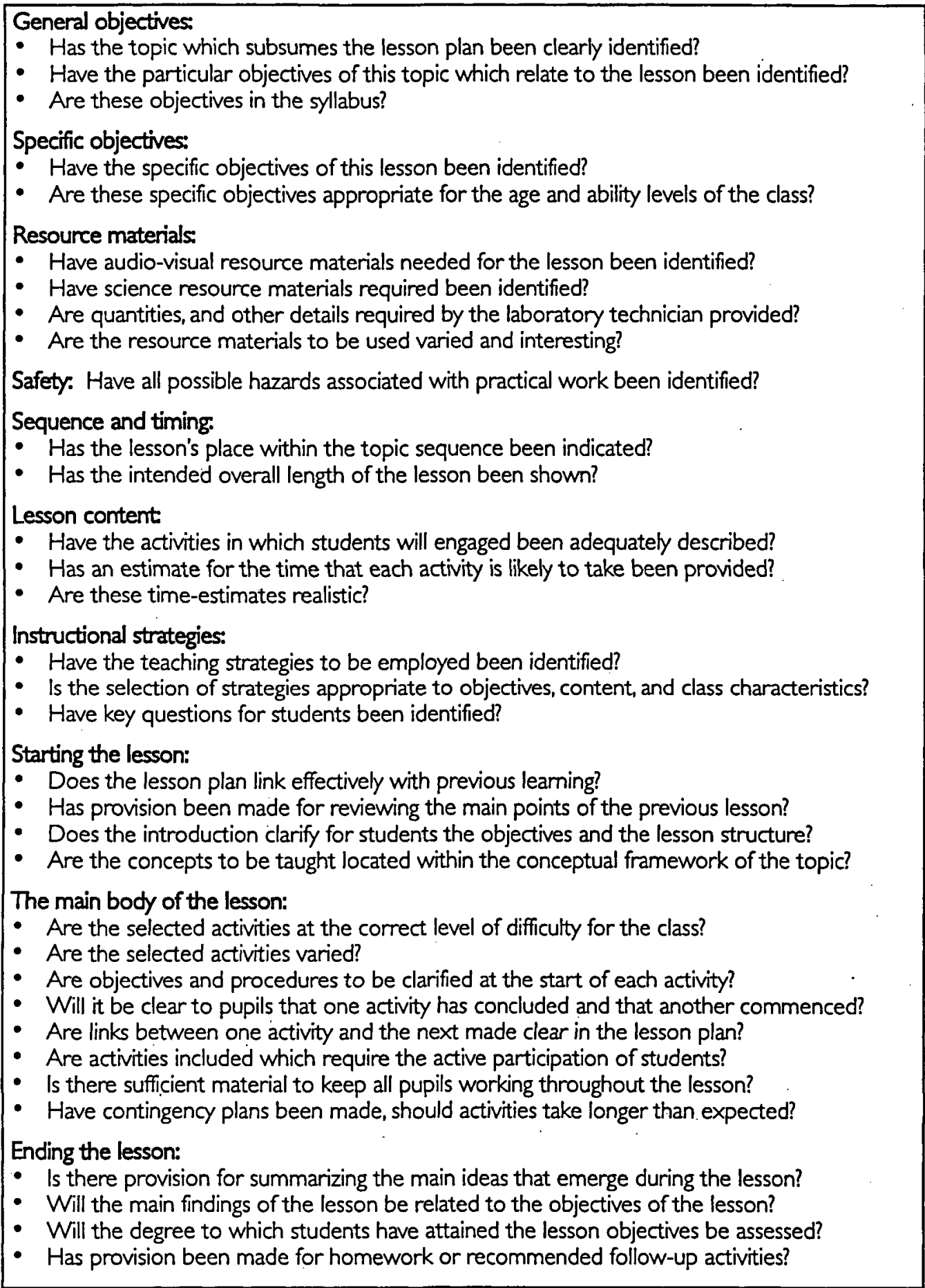

Table I: The categories of the Science Lesson Plan Rating instrument 
The first group $(N=11)$ received both the lecture and seminar in a traditional university setting. The second group $(\mathrm{N}=12)$ received the lecture at university supplemented by a school-based courseware package to be completed with the student's supervising teacher. The third group $(\mathrm{N}=10)$ and the fourth group $(\mathrm{N}=10)$ were given training in using email and an Internet browser. For these groups, the courseware used by to the first two groups was delivered via the Internet with electronic tutorial support provided by the university lecturer.

Main study instruments. An instrument called the Science Lesson Plan Rating Instrument (SLPRI) was developed for the purpose of assessing lesson planning achievement. The categories of the SLPRI are shown in Table 1.

Appraisers using the instrument are required to judge the quality of the lesson plan against a set of criteria. Using a dichotomous scoring key for each of the 34 criteria, a maximum score of 34 points could be attained.

Main study procedure. Six appraisers were selected for training in using the instrument. These six appraisers were all science-education lecturers involved in initial teacher education. After a day of intensive training in using the instrument, reliability trials were carried out. Appraisers were required to assess three sample lesson plans provided; the three appraisers with the closest agreement in assessing these lesson plans were selected to participate in the study.

Student teachers were pre-tested with respect to their lesson-planning skills by being asked to prepare a lesson on the differences between animal and plant cells. Students were then assigned to the four treatment groups and post-tested with respect to their lesson-planning skills by being asked to prepare a further lesson on the differences between animal and plant cells. To avoid experimenter-expectation effects (Barber, 1973), the roles of investigator and experimenter were separated and the investigator did not participate in data collection. The lesson plans resulting from the pre-test and post-test were randomly assigned to appraisers to avoid systematic rating errors in the results.

\section{Results}

Preliminary inventory results. As shown in Table 2, preliminary inventory data revealed that the mean number of times per week in which male student teachers used email accounts (5.14) was significantly higher than the mean number for female students (2.21). The inventory data supported the consideration of gender as a factor within the experimental design of the main study.

Main study results. Students' post-test scores on the SLPRI were converted to percentages and subjected to a two-way analysis of co-variance, with the delivery strategy (traditional or computer-mediated) and the context (university-based or partnership) as factors, and the pre-test scores as a co-variate. The results of this analysis are shown in Table 3.

\section{Discussion}

Both of the null hypotheses were rejected. Students' achievement gains were higher when computer-mediated delivery strategies were employed when compared with traditional university delivery methods (see Table 3). Also, achievement gains were higher when 
Brion M. Sovo and Roger G. Hocker Flexible learning in a partnership context for beginning teachers

\begin{tabular}{|lccccc|}
\hline Source of variance & DF & SS & MS & F-test & P value \\
\hline Between subjects & 1 & 72.043 & 72.042 & 4.346 & $<.05$ \\
Within subjects & 33 & 547.000 & 16.576 & & \\
Total & 34 & 619.042 & & & \\
\hline (Male mean = 5.14; female mean = 2.21) & & & & \\
\hline
\end{tabular}

Table 2:An analysis of variance (ANOVA) for the number of times female and male student teachers $(N=35)$ checked their email per week.

\begin{tabular}{|c|c|c|c|c|c|}
\hline Source of variation & $\begin{array}{l}\text { Sum of } \\
\text { squares }\end{array}$ & $\begin{array}{l}\text { Degrees of } \\
\text { freedom }\end{array}$ & Mean square & F ratio & $\begin{array}{l}\text { Level } \\
\text { of significance }\end{array}$ \\
\hline Delivery Strategy & 711.1 & 1 & 711.1 & 9.29 & $* *$ \\
\hline Context & 977.1 & 1 & 977.1 & 12.77 & $* * *$ \\
\hline $\begin{array}{l}\text { Interactions: } \\
\text { (two-way) }\end{array}$ & 58.67 & 1 & 58.67 & 0.767 & ns \\
\hline Explained & 2309.2 & 4 & 577.3 & 7.545 & $* * *$ \\
\hline Residual & 2907.422 & 38 & 76.5 & & \\
\hline Total & 5216.7 & 42 & 124.2 & & \\
\hline $\begin{array}{l}\text { ns } \\
* \\
* * \\
* * *\end{array}$ & $\begin{array}{l}\text { not significant, } p \\
p<0.05 \\
p \leq 0.01 \\
p \leq 0.001\end{array}$ & 0.05 & & & \\
\hline
\end{tabular}

Table 3: Post-test SLPRI scores by delivery method and context with pre-test scores as co-variate

students worked in a partnership arrangement with schools than in a traditional university-based environment.

The finding that computer-mediated delivery within a flexible learning context is more effective than traditional university teaching for an ITE courseware module is consonant with findings in other fields of study. Reasons for this greater efficacy require further study. Clark (1994) asserts that media as well as media attributes fail to influence learning, and that delivery media are not directly responsible for motivating learning. Schutte (1997) suggests that the greater efficacy of computer-mediated communications relates to the 
enhanced levels of interaction among students. The National Council for Educational Technology (NCET, 1996) suggests that advantages of computer-mediated delivery are enhanced peer-group interaction, opportunities for self-paced work and access to advice from peers, tutors and experts via the Internet on demand. Mason (1994) suggests that computer-mediated delivery can improve professional development and training by enhancing tutorial support, providing a forum for interaction between teachers and learners, and a medium for mutual support for students, facilitating access to expert debate.

The conclusion that achievement gains were higher when students worked in a partnership arrangement with schools, rather than in a traditional university-based environment, is significant in that we were unable to locate other quantitative empirical studies which had addressed this issue. This finding is supportive of policies which involve student teachers spending more time in schools and undertaking more of their educational studies in a school-based setting.

Achievement gains were 36 per cent higher for the treatment group where computermediated delivery on a flexible learning basis was employed in a partnership context, when compared with traditional delivery methods. This finding supports Attwood's $(1994,11)$ assertion that:

It is still early days in the development of formalized partnership models of teacher education, and new initiatives are yet to be fully evaluated. At present IT needs special attention, mainly because of constraints on resources and staff expertise. However, all the project reports indicated that where there was adequate staff support, a suitable resource base and a shared understanding of the appropriate use of IT in education, supported through course and assessment requirements, IT in partnership worked well.

Separate ANOVAs were carried out for the entire sample on the two factors which were controlled in the experiment, namely the year-level to which science had been studied successfully in the student's undergraduate programme, and the student's gender. The null hypothesis that the year-level to which science had been studied did not influence lessonplanning achievement was rejected $(F=5.53$ on 1 degree of freedom, $p=0.024)$, and this finding confirms that subject-matter understanding is an important factor in determining lesson-planning achievement. However, there were no significant differences in achievement associated with student gender $(F=0.03, p=0.86)$. This surprising finding suggests that although male students may make greater use of information technology as supported by the preliminary data (see also, for example, Davidson, 1995), when required to do so, female students perform on a par with their male counterparts.

\section{References}

Attwood, G. (1994), Partnerships in Initial Teacher Education: Information Technology for Tomorrow's Teachers, Coventry: National Council for Educational Technology.

Barber, T. X. (1973), 'Pitfalls in research: nine investigator and experimenter effects' in Travers, R.W. (ed), Second Handbook of Research on Teaching, New York: Rand McNally.

Clark, R. E. (1994), 'Media will never influence learning', Educational Technology Research and Development, 42 (2) 21-9. 
Davidson, K. (1995), 'Liberté, Egalité, Interneté', New Scientist, 146, 38-42.

Teaching and Learning Committee (1996), Alternative Modes of Teaching and Learning, Perth: University of Western Australia.

Mason, R. (1994), Using Communications Media in Open and Flexible Learning, London: Kogan Page.

NCET (1996), Teacher Training and Computer-Mediated Communications, Coventry: National Council for Educational Technology.

Schutte, J. G. (1997), 'Virtual teaching in higher education: the new intellectual superhighway or just another traffic jam?', http:www.csun.edu/sociology/virtexp.htm

Selinger, M. (1996), 'Beginning teachers using information technology: the Open University model', Journal of Information Technology for Teacher Education, 5 (3) 253-70. 